\title{
Corrosion of Galvanized Steel in Soils
}

\author{
Irving A. Denison and Melvin Romanoff
}

\begin{abstract}
The results of measurements of the corrosion of galvanized steel and of bare steel and zinc as reference materials after exposure to different soil conditions for a maximum of 13 years are reported. The magnitude and progress of corrosion of galvanized steel as determined by weight loss and pitting is interpreted in terms of the environmental conditions to which the specimens were exposed. From analysis of data on the corrosion of galvanized specimens having different weights of coating, minimum coating requirements for different environmental conditions are suggested.
\end{abstract}

\section{Introduction}

In order to evaluate the effectiveness of zinc coatings in protecting iron and steel from corrosion underground, test specimens of iron and steel coated with different thicknesses of zinc, applied by the hot-dip process, were included in the extensive field-exposure tests undertaken by the National Bureau of Standards in 1924. The thinner coatings did not prevent corrosion in the more corrosive soils, but coatings having a nominal weight of $3 \mathrm{oz} / \mathrm{ft}^{2}$ of exposed surface prevented the development of measurable pits on the specimens at all but one of the 47 test sites for the entire period of exposure [1, 2]. ${ }^{1}$ Although the sites represented a wide range of soil conditions, it was considered desirable to expose specimens with the heavier zinc coatings to additional soil environments in which some dominant corrosive factor, such as chloride content, acidity, etc., was the apparent cause of corrosion. Accordingly, specimens having the same nominal weight of coating, namely, $3 \mathrm{oz} / \mathrm{ft}^{2}$ of surface were buried at 15 additional sites in 1937. A sufficient number of specimens of galvanized steel and of the reference materials, steel and zinc, were buried to provide for removal of two specimens of each material after each of five periods of exposure. This paper deals with the condition of the specimens of the three materials exposed for different periods up to $13 \mathrm{yr}$.

\section{Properties of the Soils at the Test Sites}

The test sites represent a wide range of environmental conditions with respect to both the chemical and physical properties of the soils (table 1). For example, the hydrogen-ion concentration of the soils ranges from $\mathrm{pH} 2.6$ to 9.4 , and the resistivity from 62 to 17,800 ohm-cm. At several of the test sites the soils are highly oxidized to considerable depths, whereas in others the permanent water table is close to the surface. The environmental conditions at several of the test sites are illustrated in figure 1.

\section{Materials}

The galvanized and bare steel specimens were 14-in. (35-cm) lengths of pipe 1.5 in. $(3.8 \mathrm{~cm})$ in diameter cut from the same lots of commercial mate-

\footnotetext{
Figures in brackets indicate the literature references at the end of this paper.
}

rials. The nominal weight of the zinc coating on the galvanized specimens was $3.08 \mathrm{oz} / \mathrm{ft}^{2} .^{2}$ The impurities in the spelter in percent were: $\mathrm{Al}, 0.008 ; \mathrm{Fe}$, 0.07 ; and $\mathrm{Pb}, 0.78$. The steel, both galvanized and bare, was AISI No. B1010, with the nominal composition in percent as follows: C, $0.13 \max$; Mn, 0.30 to $0.60 ; \mathrm{P}, 0.07$ to $0.12 ; \mathrm{S}, 0.06 \max$. The interior of the specimens was coated with heavy grease, and the ends were closed in order to prevent internal corrosion.

The zinc specimens were plates having the dimensions $12 \mathrm{in} .(30.5 \mathrm{~cm})$ by $2.3 \mathrm{in} .(5.8 \mathrm{~cm})$ by $0.15 \mathrm{in}$. $(0.4 \mathrm{~cm})$. The impurities determined in the zinc in percent were: $\mathrm{Fe}, 0.009 ; \mathrm{Pb}, 0.095 ; \mathrm{Cd}, 0.0038$.

\section{Distribution of the Coating on the Gal- vanized Specimens}

The distribution of the coating on the galvanized specimens was measured by a magnetic method [3]. The measurements were made on one 14 -in. $(35 \mathrm{~cm})$ length of galvanized pipe selected at random from the lot of specimens before burial, and on a 6-in. $(15 \mathrm{~cm})$ section cut from a second specimen from the same lot. A total of 389 measurements of thickness were made on the 14-in. length of pipe (identified as specimen $\mathrm{A}$ ), and 162 measurements were made on the 6 -in. section (identified as specimen B).

The measurements of coating thickness are shown as frequency distribution curves in figure 2. These curves indicate not only that the specimens differed widely in coating thickness, but that the distribution of the coating on the individual specimens was highly variable as well. The variation did not fall in any particular pattern.

\section{Thickness of the Outer Zinc Coating and of the Alloy Layer}

The thickness of the outer zinc coating and of the alloy layer was measured by modifications of the electrolytic stripping methods described by Britton [4] and by Anderson and Manuel [5].

The electrolytic cell consisted of a 4-oz (120-ml) plastic bottle from which the bottom had been re-

2 This is the weight of coating on one side of the pipe. Each ounce per square foot of coating is equivalent to $0.00172 \mathrm{in}$. in thickness. 
TABLE 1. Properties of the soils at the test sites

\begin{tabular}{|c|c|c|c|c|c|c|c|c|c|c|c|c|c|c|c|}
\hline \multicolumn{3}{|c|}{ Test sites } & \multirow[b]{2}{*}{ Aeration } & \multirow[b]{2}{*}{$\begin{array}{l}\text { Moisture } \\
\text { equiva- } \\
\text { lent }\end{array}$} & \multirow[b]{2}{*}{$\begin{array}{l}\text { Apparent } \\
\text { specific } \\
\text { gravity }\end{array}$} & \multirow[b]{2}{*}{$\begin{array}{l}\text { Resistiv- } \\
\text { ity at } \\
60^{\circ}{ }^{\circ} \mathrm{F} \\
\left(15.6^{\circ} \mathrm{C}\right)\end{array}$} & \multirow[b]{2}{*}{$\mathrm{pH}$} & \multirow{2}{*}{$\begin{array}{c}\text { Total } \\
\text { acidity }{ }^{a} \\
\text { (milli- } \\
\text { gram } \\
\text { equiva- } \\
\text { lent per } \\
100 \text { g of } \\
\text { soil) }\end{array}$} & \multicolumn{7}{|c|}{ Composition of water extract (milligram equivalent per $100 \mathrm{~g}$ of soil) } \\
\hline Environment and soil type & $\begin{array}{c}\text { Soil } \\
\text { num- } \\
\text { ber }\end{array}$ & Location & & & & & & & $\begin{array}{l}\mathrm{Na}+\mathrm{K} \\
\text { as Na }\end{array}$ & $\mathrm{Ca}$ & $\mathrm{Mg}$ & $\mathrm{CO}_{3}$ & $\mathrm{HCO}_{3}$ & $\mathrm{Cl}$ & $\mathrm{SO}_{4}$ \\
\hline \multicolumn{16}{|c|}{ INORGANIC OXIDIZING-ACID SOILS } \\
\hline $\begin{array}{l}\text { Cecil clay loam } \\
\text { Hagerstown loam } \\
\text { Susquehanna clay }\end{array}$ & $\begin{array}{l}53 \\
55 \\
62\end{array}$ & $\begin{array}{l}\text { Atlanta, Ga } \\
\text { Loch Raven, Md. } \\
\text { Meridian, Miss }\end{array}$ & $\begin{array}{l}\text { Good } \\
\text { Fair do }\end{array}$ & $\begin{array}{c}\text { Percent } \\
33.7 \\
32.0 \\
34.6\end{array}$ & $\begin{array}{l}1.60 \\
1.49 \\
1.79\end{array}$ & $\begin{array}{c}\text { Ohm-cm } \\
17,800 \\
5,210 \\
6,920\end{array}$ & $\begin{array}{l}4.8 \\
5.8 \\
4.5\end{array}$ & $\begin{array}{r}5.1 \\
10.9 \\
12.0\end{array}$ & (n) & (n) & (n) & (n) & (n) & (n) & (n) \\
\hline \multicolumn{16}{|c|}{ INORGANIC OXIDIZING-ALKALINE SOILS } \\
\hline $\begin{array}{l}\text { Chino silt loam } \\
\text { Mohave fine gravelly loam }\end{array}$ & $\begin{array}{l}65 \\
66\end{array}$ & $\begin{array}{l}\text { Wilmington, Calif } \\
\text { Phoenix, Ariz }\end{array}$ & $\begin{array}{l}\text { Good } \\
\text { Fair }\end{array}$ & $\begin{array}{l}26.4 \\
16.5\end{array}$ & $\begin{array}{l}1.41 \\
1.79\end{array}$ & $\begin{array}{l}148 \\
232\end{array}$ & $\begin{array}{l}8.0 \\
8.0\end{array}$ & $\stackrel{A}{A}$ & $\begin{array}{l}7.65 \\
6.55\end{array}$ & $\begin{array}{r}12.40 \\
0.51\end{array}$ & $\begin{array}{l}2.20 \\
0.18\end{array}$ & $\begin{array}{r}0.00 \\
.00\end{array}$ & $\begin{array}{l}1.30 \\
0.73\end{array}$ & $\begin{array}{l}\text { 6. } 05 \\
2.77\end{array}$ & $\begin{array}{r}16.90 \\
2.97\end{array}$ \\
\hline \multicolumn{16}{|c|}{ INORGANIC REDUCING-ACID SOILS } \\
\hline $\begin{array}{l}\text { Acadia clay } \\
\text { Sharkey clay }\end{array}$ & $\begin{array}{l}51 \\
61\end{array}$ & $\begin{array}{l}\text { Spindletop, Tex } \\
\text { New Orleans, La }\end{array}$ & Poor & $\begin{array}{l}47.1 \\
30.8\end{array}$ & $\begin{array}{l}\text { 2. } 07 \\
\text { 1. } 78\end{array}$ & $\begin{array}{l}190 \\
943\end{array}$ & $\begin{array}{l}6.2 \\
6.8\end{array}$ & $\begin{array}{r}13.2 \\
4.9\end{array}$ & $\begin{array}{r}10.27 \\
0.73\end{array}$ & $\begin{array}{r}15.55 \\
0.68\end{array}$ & $\begin{array}{l}5.03 \\
0.33\end{array}$ & $\begin{array}{r}0.00 \\
.00\end{array}$ & $\begin{array}{r}0.56 \\
.71\end{array}$ & $\begin{array}{l}5.75 \\
0.10\end{array}$ & $\begin{array}{r}22.00 \\
0.91\end{array}$ \\
\hline \multicolumn{16}{|c|}{ INORGANIC REDUCING-ALKALINE SOILS } \\
\hline $\begin{array}{l}\text { Docas clay } \\
\text { Lake Charles clay } \\
\text { Merced silt loam }\end{array}$ & $\begin{array}{l}64 \\
56 \\
70\end{array}$ & $\begin{array}{l}\text { Cholame, Calif } \\
\text { El Vista, Tex } \\
\text { Buttonwillow, Calif }\end{array}$ & $\begin{array}{l}\text { Fair } \\
\text { Very poor } \\
\text { Fair }\end{array}$ & $\begin{array}{l}41.1 \\
28.7 \\
24.7\end{array}$ & $\begin{array}{l}\text { 1. } 88 \\
2.03 \\
1.69\end{array}$ & $\begin{array}{r}62 \\
406 \\
278\end{array}$ & $\begin{array}{l}7.5 \\
7.1 \\
9.4\end{array}$ & $\begin{array}{l}\text { A } \\
5.1 \\
\mathrm{~A}\end{array}$ & $\begin{array}{r}28.10 \\
3.12 \\
8.38\end{array}$ & $\begin{array}{r}2.29 \\
0.69 \\
.38\end{array}$ & $\begin{array}{r}0.76 \\
.47 \\
.22\end{array}$ & $\begin{array}{r}0.00 \\
.00 \\
.02\end{array}$ & $\begin{array}{r}0.89 \\
.80 \\
1.87\end{array}$ & $\begin{array}{r}28.80 \\
1.59 \\
1.12\end{array}$ & $\begin{array}{l}0.26 \\
3.04 \\
5.57\end{array}$ \\
\hline \multicolumn{16}{|c|}{ ORGANIC REDUCING-ACID SOILS } \\
\hline $\begin{array}{l}\text { Carlisle muck } \\
\text { Muck } \\
\text { Rifle peat- } \\
\text { Tidal marsh }\end{array}$ & $\begin{array}{l}59 \\
58 \\
60 \\
63\end{array}$ & $\begin{array}{l}\text { Kalamazoo, Mich } \\
\text { New Orlean, La } \\
\text { Plymouth, Ohio } \\
\text { Charleston, S. C }\end{array}$ & $\begin{array}{l}\text { Very poor } \\
\text { Poor } \\
\text { Very poor }\end{array}$ & $\begin{array}{l}43.6 \\
57.8 \\
43.4 \\
46.7\end{array}$ & $\begin{array}{l}1.43 \\
1.28 \\
1.47\end{array}$ & $\begin{array}{r}1,660 \\
712 \\
218 \\
84\end{array}$ & $\begin{array}{l}5.6 \\
4.8 \\
2.6 \\
6.9\end{array}$ & $\begin{array}{r}12.6 \\
15.0 \\
297.4 \\
14.6\end{array}$ & $\begin{array}{r}1.03 \\
2.03 \\
2.91 \\
33.60\end{array}$ & $\begin{array}{r}3.08 \\
2.23 \\
10.95 \\
6.85\end{array}$ & $\begin{array}{l}2.70 \\
1.29 \\
2.86 \\
4.00\end{array}$ & $\begin{array}{r}0.00 \\
.00 \\
.00 \\
.00\end{array}$ & $\begin{array}{r}0.00 \\
.00 \\
.00 \\
.00\end{array}$ & $\begin{array}{r}3.47 \\
0.47 \\
.00 \\
12.70\end{array}$ & $\begin{array}{r}1.04 \\
2.54 \\
56.70 \\
36.60\end{array}$ \\
\hline \multicolumn{16}{|c|}{ CINDERS } \\
\hline Cinders..... & 67 & Milwaukee, Wis....... & Very poor & ........ & -..... & 455 & 7.6 & A & 0.77 & 3.03 & 0.53 & .00 & .55 & 0.08 & 2. 89 \\
\hline
\end{tabular}

${ }^{a} \mathrm{~A}$, alkaline reaction. 
moved. The cathode was a strip of zinc 1.5 in. (38 mm) in width formed so as to fit tightly around the inner periphery of the bottle. Contact with the coating was made by means of a hole $0.19 \mathrm{in}$. $(5 \mathrm{~mm})$ in diameter in a No. 8 rubber stopper. A larger hole bored partly through one end of the stopper permitted the stopper to be placed over the mouth of the bottle. The electrolyte was a solution containing $20 \mathrm{~g}$ of $\mathrm{NaCl}, 10 \mathrm{~g}$ of $\mathrm{ZnSO}_{4}$, and $100 \mathrm{~g}$ of $\mathrm{H}_{2} \mathrm{O}$.

In operation, the bottle was inverted and the test piece placed in contact with the hole in the stopper with sufficient pressure to prevent leakage of the electrolyte. By means of a $6-v$ storage battery shunted by a variable voltage divider, an initial current of 25 ma was passed through the cell with the test piece as the anode, the current being read on a recording milliammeter. As the outer zinc coating was removed by electrolysis and different phases of zinc-iron alloy and finally steel were exposed, the changes in potential associated with each phase produced corresponding changes in the recorded current.

The interpretation of the current-time curves in terms of coating thickness is illustrated by figure 3 . The minimum thickness of the zinc laver is measured by the horizontal part of the curve at point $A$. On exposure of an alloy layer locally, the counter emf increases, and the current proportionally decreases until the zinc is completely removed and a uniform layer of the first phase of the alloy layer is exposed (point B). The current then remains unchanged until a second phase of the alloy layer is exposed and so on through the various phases until the underlying steel is completely exposed. The minimum thickness of the alloy layer, including the intermediate phases, is represented by the distance $B C$, and the maximum thickness by the distance $A D$. The reported thicknesses were computed from the areas under the curve. For the present investigation the thickness of the zinc coating was taken as the maximum thickness, that is, to point $B$, and the thickness of the alloy layer was taken as being represented by the distance $B D$.

The maximum thickness of the outer zinc coating and of the alloy layer at several points on two specimens are recorded in table 2 . These data indicate that a large part of the zinc applied to the steel pipe was converted to alloy layer.

TABLE 2. Thickness of the outer zinc coating, of the alloy layer, and of the total coating on galvanized specimens

[In mils]

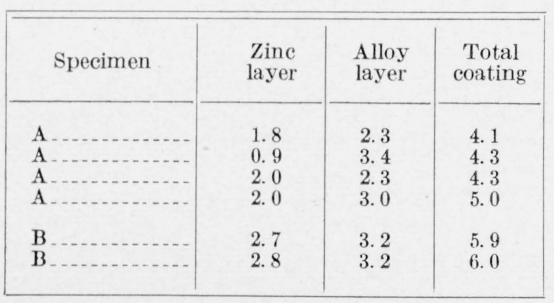

\section{Condition of Coating, Weight Loss, and Pitting of Galvanized Steel, Bare Steel, and Zinc}

After each exposure period, one set of specimens was removed, returned to the laboratory, and cleaned free of corrosion products by previously described methods [2]. Photographs of the specimens of galvanized steel, bare steel, and zinc removed from the different sites after exposure for $13 \mathrm{yr}$ are shown in figure 4.

The losses in weight and the depths of the deepest pits on the specimens, together with the percentage of the area of the galvanized specimens on which coating remained, are recorded in table 3 for the different periods of exposure. Except as indicated, each value is the average of measurements made on two specimens.

The data of table 3 reveal that in nearly one-half of the total number of soils $(53,55,61,62,64,65,66$, and 70 ) the coating remained virtually intact and consequently provided complete protection to the underlying steel for the maximum period of exposure. However, in the highly reducing soils $(51,56,58$, and 60 ) and in cinders (67) little, if any, of the coating remained at the conclusion of the test.

In certain soils, such as 58 and 60 , failure of the coating during the first few years of exposure resulted in a rate of corrosion of the galvanized specimens comparable to that of bare steel. But in other soils, contrary to expectations, destruction of the coating was not accompanied by rapid corrosion of the underlying steel. For example, the galvanized specimens in soils 51 and 56 corroded relatively slowly during the greater part of the exposure period in spite of the fact that the coating was almost completely removed by corrosion during the first few years of exposure. Even in the highly corrosive cinders, soil 67 , the galvanized specimens corroded much more slowly than the specimens of bare steel.

The progress of corrosion of galvanized steel, bare steel, and zinc in the different soils is shown by the weight loss and pit depth-time curves of figure 5 . The values for weight loss and pitting of the galvanized specimens on which the coating remained intact naturally apply to the coating and not to the basis metal.

The weight loss and pit-depth-time curves for the galvanized specimens in soils $64,65,66$, and 70 are of particular interest in indicating that zinc coatings were effective in protecting steel against corrosion in soils that are highly corrosive to steel, For example, in spite of the fact that the steel specimens in soil 66 were perforated by corrosion afterexposure for a few years, the coating on the galvanized specimens in this soil remained perfectly continuous throughout the entire period of the test. In soil 70 , the specimens of both zinc and steel were severely corroded, but the coating on the galvanized specimens provided complete protection to the underlying steel. 
TABLE 3. Loss in weight and maximum penetration of galvanized ${ }^{a}$ and bare steel pipe and zinc plate

[A verage of two specimens]

\begin{tabular}{|c|c|c|c|c|c|c|c|c|c|c|c|c|}
\hline \multirow{3}{*}{$\begin{array}{l}\text { Soil } \\
\text { No. }\end{array}$} & \multirow{3}{*}{ Soil type } & \multirow{3}{*}{ Exposure } & \multicolumn{6}{|c|}{ Galvanized steel } & \multicolumn{2}{|c|}{ Bare steel } & \multicolumn{2}{|c|}{ Zine } \\
\hline & & & \multicolumn{4}{|c|}{ Condition of surface } & \multirow[b]{2}{*}{$\begin{array}{l}\text { Loss in } \\
\text { weight }\end{array}$} & \multirow[b]{2}{*}{$\begin{array}{c}\text { Maximum } \\
\text { penetration }\end{array}$} & \multirow[b]{2}{*}{$\begin{array}{l}\text { Loss in } \\
\text { weight }\end{array}$} & \multirow[b]{2}{*}{$\underset{\text { penetration }}{\text { Maximum }}$} & \multirow[b]{2}{*}{$\begin{array}{l}\text { Loss in } \\
\text { weight }\end{array}$} & \multirow[b]{2}{*}{$\begin{array}{l}\text { Maximum } \\
\text { penetration }\end{array}$} \\
\hline & & & $\begin{array}{l}\text { Coated with } \\
\text { zine and } \\
\text { alloy layer }\end{array}$ & $\begin{array}{l}\text { Coated with } \\
\text { zinc }\end{array}$ & $\begin{array}{l}\text { Coated with } \\
\text { alloy layer }\end{array}$ & $\begin{array}{l}\text { Bare stee? } \\
\text { exposed }\end{array}$ & & & & & & \\
\hline \multicolumn{13}{|c|}{ INORGANIC OXIDIZING-ACID SOILS } \\
\hline 53 & Cecil clay loam & $\begin{array}{c}\text { Years } \\
2.1 \\
4.0 \\
8.9 \\
11.2 \\
12.7\end{array}$ & $\begin{array}{r}\text { Percent } \\
85 \text { to } 100 \\
100 \\
100 \\
100 \\
100\end{array}$ & $\begin{array}{l}\text { Percent } \\
60 \text { to } 100 \\
20 \text { to } 40 \\
20 \text { to } 40 \\
30 \\
20\end{array}$ & $\begin{array}{c}\text { Percent } \\
0 \text { to } 40 \\
60 \text { to } 80 \\
60 \text { to } 80 \\
70 \\
80\end{array}$ & $\begin{array}{c}\text { Percent } \\
0 \\
0 \\
0 \\
0 \\
0\end{array}$ & $\begin{array}{c}o z / f t^{2} \\
0.3 \\
1.4 \\
0.6 \\
1.0 \\
0.6\end{array}$ & $\begin{array}{r}\text { Mils } \\
9 \\
6 \\
<6 \\
<6 \\
<6\end{array}$ & $\begin{array}{c}o z / f t^{2} \\
1.8 \\
2.9 \\
3.4 \\
3.4 \\
3.9\end{array}$ & $\begin{array}{r}\text { Mils } \\
42 \\
98 \\
74 \\
78 \\
68\end{array}$ & $\begin{array}{c}o z / f t^{2} \\
0.2 \\
.6 \\
1.1 \\
1.6 \\
2.2\end{array}$ & $\begin{array}{c}\text { Mils } \\
10 \\
10 \\
13 \\
16 \\
17\end{array}$ \\
\hline 55 & Hagerstown loam .. & $\begin{array}{r}1.9 \\
3.9 \\
9.0 \\
11.0 \\
12.6\end{array}$ & $\begin{array}{r}100 \\
100 \\
95 \\
100 \\
100\end{array}$ & $\begin{array}{c}60 \text { to } 100 \\
20 \text { to } 40 \\
20 \text { to } 40 \\
70 \\
70\end{array}$ & $\begin{array}{l}0 \text { to } 40 \\
60 \text { to } 80 \\
55 \text { to } 75 \\
30 \\
30\end{array}$ & $\begin{array}{r}0 \\
0 \\
<5 \\
0 \\
0\end{array}$ & $\begin{array}{r}.3 \\
1.2 \\
0.7 \\
1.0 \\
0.6\end{array}$ & $\begin{array}{r}<6 \\
8 \\
6 \\
<6 \\
<6\end{array}$ & $\begin{array}{l}1.8 \\
2.6 \\
4.1 \\
3.9 \\
3.4\end{array}$ & $\begin{array}{l}33 \\
50 \\
92 \\
84 \\
73\end{array}$ & $\begin{array}{r}0.4 \\
.6 \\
.7 \\
1.3 \\
1.2\end{array}$ & $\begin{array}{r}13 \\
8 \\
8 \\
10 \\
9\end{array}$ \\
\hline 62 & Susquehanna clay & $\begin{array}{r}2.1 \\
4.0 \\
8.9 \\
11.2 \\
12.7\end{array}$ & $\begin{array}{l}100 \\
100 \\
100 \\
100 \\
100\end{array}$ & $\begin{array}{l}50 \text { to } 100 \\
20 \text { to } 40 \\
0 \text { to } 20 \\
80 \\
75\end{array}$ & $\begin{array}{l}0 \text { to } 50 \\
60 \text { to } 80 \\
80 \text { to } 100 \\
20 \\
25\end{array}$ & $\begin{array}{l}0 \\
0 \\
0 \\
0 \\
0\end{array}$ & $\begin{array}{l}1.0 \\
2.3 \\
0.9 \\
1.1 \\
0.8\end{array}$ & $\begin{array}{r}12 \\
9 \\
<6 \\
<6 \\
<6\end{array}$ & $\begin{array}{l}3.2 \\
4.3 \\
5.3 \\
6.0 \\
6.8\end{array}$ & $\begin{array}{l}40 \\
56 \\
68 \\
72 \\
79\end{array}$ & $\begin{array}{l}0.6 \\
1.2 \\
1.3 \\
1.3 \\
1.7\end{array}$ & $\begin{array}{r}9 \\
9 \\
12 \\
11 \\
9\end{array}$ \\
\hline \multicolumn{13}{|c|}{ INORGANIC OXIDIZING-ALKAIINE SOILS } \\
\hline 65 & Chino silt loam ... & $\begin{array}{r}2.1 \\
4.0 \\
9.0 \\
11.2 \\
12.7\end{array}$ & $\begin{array}{r}100 \\
100 \\
95 \\
95 \\
100\end{array}$ & $\begin{array}{c}20 \text { to } 40 \\
0 \text { to } 20 \\
50 \text { to } 75 \\
0 \\
0\end{array}$ & $\begin{array}{l}60 \text { to } 80 \\
80 \text { to } 100 \\
25 \text { to } 50 \\
95 \\
100\end{array}$ & $\begin{array}{r}0 \\
0 \\
<5 \\
<5 \\
0\end{array}$ & $\begin{array}{l}1.1 \\
2.3 \\
1.6 \\
1.7 \\
1.1\end{array}$ & $\begin{array}{r}<6 \\
6 \\
<6 \\
<6 \\
<6\end{array}$ & $\begin{array}{l}4.3 \\
4.6 \\
\text { 7. } 0 \\
6.2 \\
7.2\end{array}$ & $\begin{array}{l}50 \\
59 \\
65 \\
84 \\
98\end{array}$ & $\begin{array}{r}0.5 \\
.8 \\
1.4 \\
1.1 \\
1.8\end{array}$ & $\begin{array}{l}30 \\
36 \\
56 \\
40 \\
56\end{array}$ \\
\hline 66 & Mohave fine gravelly loam . & $\begin{array}{r}2.1 \\
4.0 \\
9.0 \\
11.2 \\
12.7\end{array}$ & $\begin{array}{r}100 \\
100 \\
95 \\
95 \\
100\end{array}$ & $\begin{array}{c}60 \text { to } 100 \\
20 \text { to } 40 \\
20 \text { to } 40 \\
0 \\
0\end{array}$ & $\begin{array}{c}0 \text { to } 40 \\
60 \text { to } 80 \\
60 \text { to } 80 \\
95 \\
100\end{array}$ & $\begin{array}{l}0 \\
0 \\
5 \\
5 \\
0\end{array}$ & $\begin{array}{l}1.6 \\
3.3 \\
1.1 \\
2.7 \\
1.1\end{array}$ & $\begin{array}{r}6 \\
8 \\
<6 \\
<6 \\
<6\end{array}$ & $\begin{array}{r}9.2 \\
12.3 \\
8.1 \\
16.3 \\
\text { b } 20.3\end{array}$ & $\begin{array}{c}d 145+ \\
145+ \\
78 \\
145+ \\
145+\end{array}$ & $\begin{array}{r}1.7 \\
82.6 \\
0.9 \\
4.4 \\
5.5\end{array}$ & $\begin{array}{l}25 \\
28 \\
44 \\
56 \\
34\end{array}$ \\
\hline \multicolumn{13}{|c|}{ INORGANIC REDUCING-ACID SOILS } \\
\hline 61 & Sharkey clay & $\begin{array}{r}2.1 \\
4.0 \\
8.9 \\
11.2 \\
12.7\end{array}$ & $\begin{array}{r}100 \\
100 \\
95 \\
95 \\
100\end{array}$ & $\begin{array}{c}60 \text { to } 100 \\
20 \text { to } 40 \\
75 \text { to } 95 \\
0 \\
0\end{array}$ & $\begin{array}{c}0 \text { to } 40 \\
60 \text { to } 80 \\
5 \text { to } 20 \\
95 \\
100\end{array}$ & $\begin{array}{r}0 \\
0 \\
<5 \\
<5 \\
0\end{array}$ & $\begin{array}{l}0.6 \\
1.5 \\
0.7 \\
2.2 \\
1.1\end{array}$ & $\begin{array}{r}6 \\
12 \\
<6 \\
6 \\
6\end{array}$ & $\begin{array}{l}2.2 \\
5.0 \\
4.2 \\
6.9 \\
7.5\end{array}$ & $\begin{array}{l}40 \\
45 \\
48 \\
58 \\
64\end{array}$ & $\begin{array}{l}0.5 \\
1.0 \\
1.1 \\
2.1 \\
2.0\end{array}$ & $\begin{array}{r}12 \\
8 \\
14 \\
17 \\
14\end{array}$ \\
\hline 51 & Acadia clay .... & $\left\{\begin{array}{r}2.1 \\
\times 9.0\end{array}\right.$ & $\begin{array}{r}15 \\
<5\end{array}$ & $\begin{array}{l}0 \\
0\end{array}$ & $\begin{array}{r}15 \\
<5\end{array}$ & $\begin{array}{l}85 \\
95\end{array}$ & $\begin{array}{l}3.3 \\
4.8\end{array}$ & $\begin{array}{l}6 \\
8\end{array}$ & $\begin{array}{r}7.5 \\
17.4\end{array}$ & $\begin{array}{c}52 \\
128+\end{array}$ & $\begin{array}{l}2.0 \\
4.8\end{array}$ & $\begin{array}{l}30 \\
28\end{array}$ \\
\hline
\end{tabular}




\begin{tabular}{|c|c|c|c|c|c|c|c|c|c|c|c|c|}
\hline 64 & Docas clay ... & $\begin{array}{r}2.1 \\
4.0 \\
9.0 \\
11.2 \\
12.8\end{array}$ & $\begin{array}{r}100 \\
100 \\
95 \\
95 \\
95\end{array}$ & $\begin{array}{r}0 \text { to } 20 \\
20 \text { to } 50 \\
75 \text { to } 95 \\
0 \\
0\end{array}$ & $\begin{array}{r}80 \text { to } 100 \\
50 \text { to } 100 \\
5 \text { to } 20 \\
95 \\
95\end{array}$ & $\begin{array}{r}0 \\
0 \\
<5 \\
5 \\
<5\end{array}$ & $\begin{array}{l}3.2 \\
1.6 \\
1.6 \\
2.4 \\
1.6\end{array}$ & $\begin{array}{r}8 \\
9 \\
10 \\
<6 \\
<6\end{array}$ & $\begin{array}{r}8.7 \\
6.0 \\
4.7 \\
12.4 \\
\text { b } 17.2\end{array}$ & $\begin{array}{r}80 \\
67 \\
80 \\
118 \\
122\end{array}$ & $\begin{array}{l}0.7 \\
.6 \\
1.4 \\
1.6 \\
2.0\end{array}$ & $\begin{array}{r}16 \\
18 \\
79 \\
35 \\
b 21\end{array}$ \\
\hline 70 & Merced silt loam . : & $\begin{array}{r}2.1 \\
4.0 \\
9.0 \\
11.2 \\
12.8\end{array}$ & $\begin{array}{r}100 \\
100 \\
100 \\
85 \\
90\end{array}$ & $\begin{array}{r}60 \text { to } 100 \\
0 \text { to } 20 \\
20 \text { to } 40 \\
0 \\
0\end{array}$ & $\begin{array}{r}0 \text { to } 40 \\
80 \text { to } 100 \\
60 \text { to } 80 \\
85 \\
90\end{array}$ & $\begin{array}{r}0 \\
0 \\
0 \\
15 \\
10\end{array}$ & $\begin{array}{l}2.1 \\
4.5 \\
0.1 \\
2.6 \\
1.3\end{array}$ & $\begin{array}{r}8 \\
12 \\
6 \\
8 \\
8\end{array}$ & $\begin{array}{r}4.9 \\
\text { b } 9.7 \\
13.4 \\
24.5 \\
21.3\end{array}$ & $\begin{array}{l}50 \\
518+ \\
122 \\
145+ \\
145+\end{array}$ & $\begin{array}{c}1.7 \\
01.6 \\
3.6 \\
\mathrm{D} \\
\mathrm{D}\end{array}$ & $\begin{array}{c}56 \\
102+ \\
84 \\
150+ \\
150+\end{array}$ \\
\hline 56 & Lake Charles clay ... & $\begin{array}{r}2.1 \\
4.0 \\
8.9 \\
11.1 \\
12.7\end{array}$ & $\begin{array}{r}5 \text { to } 15 \\
5 \text { to } 15 \\
<5 \\
<5 \\
<5\end{array}$ & $\begin{array}{l}0 \\
0 \\
0 \\
0 \\
0\end{array}$ & $\begin{array}{r}5 \text { to } 15 \\
5 \text { to } 15 \\
\quad<5 \\
<5 \\
<5\end{array}$ & $\begin{array}{r}85 \text { to } 95 \\
85 \text { to } 95 \\
95 \\
95 \\
95\end{array}$ & $\begin{array}{r}3.7 \\
3.9 \\
5.5 \\
14.3 \\
13.8\end{array}$ & $\begin{array}{r}5 \\
7 \\
13 \\
26 \\
66\end{array}$ & $\begin{array}{l}13.8 \\
16.0 \\
27.8 \\
f \mathrm{D} \\
\mathrm{D}\end{array}$ & $\begin{array}{c}77 \\
104 \\
145+ \\
145+ \\
145+\end{array}$ & $\begin{array}{r}1.1 \\
3.4 \\
4.5 \\
6.6 \\
b 9.0\end{array}$ & $\begin{array}{r}10 \\
26 \\
29 \\
42 \\
653\end{array}$ \\
\hline \multicolumn{13}{|c|}{ ORGANIC REDUCING-ACID SOILS } \\
\hline 59 & Carlisle muck... & $\begin{array}{r}2.1 \\
4.0 \\
9.1 \\
11.1 \\
12.7\end{array}$ & $\begin{array}{r}30 \text { to } 50 \\
30 \text { to } 50 \\
50 \\
50 \\
40\end{array}$ & $\begin{array}{l}0 \\
0 \\
0 \\
0 \\
0\end{array}$ & $\begin{array}{r}0 \\
0 \\
20 \text { to } 50 \\
50 \\
40\end{array}$ & $\begin{array}{r}50 \text { to } 70 \\
50 \text { to } 70 \\
50 \\
50 \\
60\end{array}$ & $\begin{array}{l}1.2 \\
3.4 \\
3.0 \\
4.0 \\
3.4\end{array}$ & $\begin{array}{r}8 \\
11 \\
8 \\
8 \\
<6\end{array}$ & $\begin{array}{l}1.5 \\
3.3 \\
7.5 \\
9.6 \\
9.6\end{array}$ & $\begin{array}{r}12 \\
20 \\
101 \\
76 \\
72\end{array}$ & $\begin{array}{l}0.7 \\
1.7 \\
4.6 \\
3.9 \\
4.6\end{array}$ & $\begin{array}{l}66 \\
10 \\
22 \\
28 \\
18\end{array}$ \\
\hline 63 & Tidal marsh & $\begin{array}{r}2.1 \\
4.0 \\
8.9 \\
11.2 \\
12.6\end{array}$ & $\begin{array}{r}100 \\
100 \\
95 \\
75 \\
60\end{array}$ & $\begin{array}{r}50 \text { to } 100 \\
50 \text { to } 100 \\
0 \\
0 \\
0\end{array}$ & $\begin{array}{r}0 \text { to } 50 \\
0 \text { to } 50 \\
95 \\
75 \\
60\end{array}$ & $\begin{array}{r}0 \\
0 \\
5 \\
25 \\
40\end{array}$ & $\begin{array}{r}1.2 \\
2.1 \\
2.0 \\
2.9 \\
b 4.8\end{array}$ & $\begin{array}{r}<6 \\
10 \\
8 \\
8 \\
852\end{array}$ & $\begin{array}{r}2.7 \\
9.2 \\
10.7 \\
12.2 \\
18.5\end{array}$ & $\begin{array}{r}24 \\
38 \\
80 \\
94 \\
126\end{array}$ & 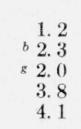 & $\begin{array}{l}26 \\
34 \\
25 \\
30 \\
43\end{array}$ \\
\hline 58 & Muck & $\begin{array}{r}2.1 \\
4.0 \\
9.1 \\
11.1 \\
12.7\end{array}$ & $\begin{array}{r}5 \text { to } 15 \\
0 \\
0 \\
0 \\
0\end{array}$ & $\begin{array}{l}0 \\
0 \\
0 \\
0 \\
0\end{array}$ & 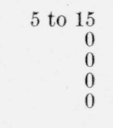 & $\begin{array}{r}85 \text { to } 95 \\
100 \\
100 \\
100 \\
100\end{array}$ & $\begin{array}{r}4.3 \\
5.4 \\
9.0 \\
8.3 \\
10.7\end{array}$ & $\begin{array}{r}13 \\
b 21 \\
64 \\
66 \\
76\end{array}$ & $\begin{array}{r}5.1 \\
8.8 \\
17.3 \\
16.3 \\
17.6\end{array}$ & $\begin{array}{r}29 \\
46 \\
98 \\
110 \\
124\end{array}$ & $\begin{array}{l}3.3 \\
5.1 \\
7.4 \\
7.6 \\
7.5\end{array}$ & $\begin{array}{l}38 \\
66 \\
58 \\
75 \\
50\end{array}$ \\
\hline 60 & Rifle peat & $\begin{array}{r}2.1 \\
4.0 \\
9.1 \\
11.1 \\
12.7\end{array}$ & $\begin{array}{l}0 \\
0 \\
0 \\
0 \\
0\end{array}$ & $\begin{array}{l}0 \\
0 \\
0 \\
0 \\
0\end{array}$ & $\begin{array}{l}0 \\
0 \\
0 \\
0 \\
0\end{array}$ & $\begin{array}{l}100 \\
100 \\
100 \\
100 \\
100\end{array}$ & $\begin{array}{r}4.3 \\
7.2 \\
19.8 \\
17.9 \\
19.5\end{array}$ & $\begin{array}{l}10 \\
12 \\
83+ \\
66 \\
88\end{array}$ & $\begin{array}{r}4.0 \\
8.1 \\
17.6 \\
19.6 \\
21.0\end{array}$ & $\begin{array}{r}15 \\
838 \\
58 \\
89 \\
118\end{array}$ & $\begin{array}{c}4.6 \\
10.4 \\
D \\
D \\
D\end{array}$ & $\begin{array}{l}53 \\
100 \\
150+ \\
150+ \\
150+\end{array}$ \\
\hline \multicolumn{13}{|c|}{ CINDERS } \\
\hline 67 & Cinders & $\begin{array}{r}2.1 \\
4.0 \\
9.0 \\
11.1 \\
12.7\end{array}$ & $\begin{array}{r}0 \\
0 \\
<5 \\
0 \\
<5\end{array}$ & $\begin{array}{l}0 \\
0 \\
0 \\
0 \\
0\end{array}$ & $\begin{array}{r}0 \\
0 \\
<5 \\
0 \\
<5\end{array}$ & $\begin{array}{r}100 \\
100 \\
95 \\
100 \\
95\end{array}$ & $\begin{array}{r}6.7 \\
5.4 \\
5.6 \\
17.2 \\
\text { b } 11.9\end{array}$ & $\begin{array}{r}62 \\
45 \\
21 \\
62 \\
648\end{array}$ & $\begin{array}{r}40.5 \\
\text { e } 37.0 \\
31.7 \\
\text { D } \\
\text { D }\end{array}$ & $\begin{array}{l}145+ \\
145+ \\
145+ \\
145+ \\
145+\end{array}$ & 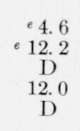 & $\begin{array}{c}107+ \\
118+ \\
150+ \\
78 \\
150+\end{array}$ \\
\hline
\end{tabular}


The weight loss and pit depth-time curves for the galvanized specimens (fig. 5) show that the zinc coatings provided good protection in all of the 10 inorganic soils with the exception of the highly reducing soil 56. However, in only one of the four organic soils (59) could protection be considered adequate. In two of these soils, 58 and 60 , the effectiveness of the zinc coating was negligible. Although it is not surprising that severe corrosion of galvanized steel occurred in these organic soils because of their corrosiveness toward zinc, it is evident from the curves in figure 5 that a high rate of corrosion of zinc in a soil does not indicate necessarily that galvanized steel would also be subject to corrosion.

The data presented on the condition of the coating on the specimens (table 3 ) indicate that the specimens removed from sites $64,65,66$, and 7.0 after exposures for 11 and for $13 \mathrm{yr}$ contained no zinc whatever. Because these specimens were covered with zinc-iron alloy layer, it might be assumed that the alloy layer protected the steel pipe electrochemically or otherwise, but unpublished results of measurements of the potentials and of the polarizing characteristics of these materials, supplemented by measurements of weight loss, indicate that the zinciron alloy layer cannot protect steel cathodically in soils, nor is it more resistant to corrosion than steel.

Additional evidence that galvanic action between zinc and steel does not fully account for the behavior of the galvanized specimens is provided by the data on weight loss and pitting of the specimens removed from sites 51 and 67 (table 3). Although both the outer zinc coating and the alloy layer were completely removed from the specimens during the initial period of exposure, the weight losses and pitting of the galvanized specimens during the remaining periods of exposure were considerably less than they were on the bare steel specimens. There are some indications that the relatively high resistance to corrosion of the galvanized specimens is due to an inorganic film or coating deposited by galvanic action between the outer zinc coating and the alloy layer or steel. The composition and properties of this film, which is presumably silicious in nature, are currently under study.

Reference has previously been made to an earlier series of field tests in which were included galvanized specimens having the same nominal weight of coating as those in the present test, namely, $3 \mathrm{oz} / \mathrm{ft}^{2}[1,2]$. In comparing the behavior of these two sets of specimens, Blum and Brenner [6] concluded that the specimens in the later test corroded as a group as much in $4 \mathrm{yr}$ as did the specimens in the earlier test in $10 \mathrm{yr}$. A further examination of these data, however, indicates that this observation is not entirely correct. The data for the 1924 specimens removed after 10 yr are reported as an average rate of loss of weight in ounces per square foot (or penetration) per year, whereas those for the 1937 specimens are reported as total loss of weight (or total penetration) after 4 yr exposure. Comparison of the two sets of specimens on this basis is difficult because most corrosion occurs during the first few years of exposure and the rate decreases considerably after this initial rapid corrosion.

A better comparison may be made of the two sets of specimens after each had been exposed for $10 \mathrm{yr}$. Seven of the soil sites either were common to the two series of tests or were located in soils of the same type, differing only in geographical location, making possible a comparison of the two sets under the same soil conditions. The weight losses and the maximum penetration of these specimens, both bare and galvanized, exposed to the same soil conditions are given in table 4 . Because the specimens buried in 1937 were not removed after exposure for $10 \mathrm{yr}$ as were the earlier specimens, it was necessary to interpolate the weight loss and pit depth-time curves for these specimens (fig. 5) between the points for 9 and

TAвLE 4. Comparison between different lots of 3-oz galvanized samples exposed to the same soil conditions for 2 different 10 yr periods

\begin{tabular}{|c|c|c|c|c|c|c|c|}
\hline \multirow{2}{*}{\multicolumn{2}{|c|}{ Site number }} & \multicolumn{4}{|c|}{ Galvanized steel } & \multirow{2}{*}{\multicolumn{2}{|c|}{$\begin{array}{l}\text { Bare steel, } \\
\text { weight loss }\end{array}$}} \\
\hline & & \multicolumn{2}{|c|}{ Weight loss } & \multicolumn{2}{|c|}{$\begin{array}{l}\text { Maximum } \\
\text { penetration }\end{array}$} & & \\
\hline 1924 & 1937 & 1924 & 1937 & 1924 & 1937 & 1924 & 1937 \\
\hline & & $o z / f t^{2}$ & $o z / f t^{2}$ & Mils & Mils & $0 z / f t^{2}$ & \\
\hline 3 & 53 & 0.4 & 0.8 & $<6$ & $<6$ & 4. 0 & 4. 0 \\
\hline 11 & 55 & .9 & 1.0 & $<6$ & 9 & 1.8 & 4. 0 \\
\hline 23 & 70 & 9.6 & 1.5 & 68 & 7 & 25. 7 & 18.5 \\
\hline 29 & 58 & 6.0 & 8.5 & $<6$ & 63 & 14.8 & 16.8 \\
\hline 40 & 61 & 0.9 & 1.5 & $<6$ & $<6$ & 7.5 & 5.5 \\
\hline 42 & 62 & 0.7 & 1. 0 & $<6$ & $<6$ & 10.6 & 5.5 \\
\hline a 43 & 63 & 1. 4 & 2.5 & $<6$ & 8 & 12.7 & 11.5 \\
\hline
\end{tabular}

a Site 43 is not identical with site 63 geographically, but the soil environment, tidal marsh, is the same.

$13 \mathrm{yr}$. In 5 of the soils, 3 (53), 11 (55), 40 (61), $42(62)$, and 43 (63) there is no significant difference in corrosion. In two soils, 23 (70) and 29 (58) real differences, particularly in penetration, are found. In the case of soil 23 (70) the penetration was greater in the 1924 specimens, but in the other, 29 (58), the penetration was greater in the 1937 specimens.

As pointed out previously there is a wide range in coating thickness of the specimens buried in 1937 (fig. 2) and a similar but somewhat smaller range in the 1924 specimens. The excellent agreement in results of the tests of the two sets of specimens in five soils indicate that these thickness differences were of little significance and that the difference in corrosion of the specimens in the other two soils must have been due to local environmental changes, such as drainage, aeration, etc. over the two periods of time.

\section{Effect of Weight of Coating}

Logan and Ewing [1] studied the effect of weight of coating on the loss in weight of galvanized specimens exposed to corrosion in six soils, representing a wide range of conditions, for periods of 6,8 , and $10 \mathrm{yr}$. Their results showed that the weight loss decreased with increase in weight of coating to a 
certain limiting value beyond which it was constant. On the basis of this relation and other considerations, the conclusion was drawn that galvanized coatings for underground use should have a weight of not less than $2 \mathrm{oz} / \mathrm{ft}^{2}$ of exposed surface. Although Logan and Ewing showed a rough correlation between weight loss and pitting, no attempt was made to relate the rate of pitting of the specimens directly to coating weight.

In order to obtain a direct relation between the pitting of galvanized steel specimens and weight of coating, the depths of the deepest pits after 10-yr exposure on the specimens studied by Logan and Ewing were averaged for the same six soils and plotted against the corresponding weights of coating. In obtaining the values shown in figure 6 , the pit depths on specimens having coating weights within the ranges 0.8 to $0.9,0.9$ to 1.0 , etc. $\mathrm{oz} / \mathrm{ft}^{2}$ were averaged. These average values also include data for specimens of different basis metals, namely, open-hearth iron, wrought iron and copper bearing steel, no specific effect of the basis metal on weight loss having been observed. Each point shown in figure 6 is the average of measurements made on from 12 to 36 specimens, usually the latter. The values for the standard deviation of the pit depths for the different coating thicknesses are seen to decrease markedly with increase in coating thickness. For the soil conditions represented, a zinc coating having a nominal weight of $2 \mathrm{oz} / \mathrm{ft}^{2}$ of exposed surface would prevent appreciable pitting

TABLE 5. Condition or maximum penetration of galvanized pipe and 16-gage steel sheet

[Maximum penetration, in mils]

Z, Zinc continuous over specimen; A, zinc-iron alloy laver exposed over at least a part of the specimen; R, rusted; M, shallow metal attack.

\begin{tabular}{|c|c|c|c|c|c|c|}
\hline \multirow{3}{*}{ Soil number } & \multicolumn{6}{|c|}{ Coating weight $\left(\mathrm{oz} / \mathrm{ft}^{2}\right)$ on- } \\
\hline & \multicolumn{3}{|c|}{ Sheet ${ }^{a}$} & \multicolumn{3}{|c|}{ Pipe } \\
\hline & 0.81 & 0.99 & 1.07 & 1.81 & 2.82 & 3.08 \\
\hline
\end{tabular}

INORGANIC OXIDIZING-ACID SOILS

\begin{tabular}{|c|c|c|c|c|c|c|}
\hline 3 & $\mathrm{R}$ & $\mathrm{R}$ & $\mathrm{Z}$ & M & $\mathrm{Z}$ & \\
\hline $\begin{array}{r}53 \\
4\end{array}$ & 16 & 22 & 13 & $\mathrm{R}$ & & A \\
\hline $\begin{array}{l}4 \\
6\end{array}$ & A & A & $\begin{array}{c}13 \\
Z\end{array}$ & & $\pi$ & . \\
\hline 10 & 24 & 16 & 12 & A & $\mathrm{R}$ & - n \\
\hline 11 & 21 & 16 & 13 & $\ldots$ & A & \\
\hline $\begin{array}{l}55 \\
12\end{array}$ & $M$ & $\mathrm{~A}$ & $\mathrm{~A}$ & $\mathrm{~A}$ & - & A \\
\hline 16 & 15 & 20 & $\begin{array}{l}1 \\
18\end{array}$ & Z & $\mathrm{M}^{-}$ & - \\
\hline 19 & 20 & 27 & 22 & A & Z & - \\
\hline 22 & 32 & 56 & 29 & & $\mathrm{R}$ & $\ldots$ \\
\hline 24 & A & A & $\mathrm{Z}$ & $\mathrm{Z}$ & Z & ...... \\
\hline 25 & $\mathrm{R}$ & 10 & $\mathrm{R}$ & -... & Z & ....... \\
\hline $\begin{array}{l}26 \\
31\end{array}$ & $\begin{array}{r}6 \\
\mathbf{A}\end{array}$ & $\begin{array}{c}11 \\
Z\end{array}$ & $\begin{array}{l}8 \\
Z\end{array}$ & A & $\begin{array}{c}\text { A } \\
\text { Z }\end{array}$ & - \\
\hline 32 & $\mathrm{R}$ & A & A & $\mathrm{R}$ & $\mathrm{R}$ & $\ldots$ \\
\hline 35 & $\mathrm{R}$ & A & A & A & A & ....... \\
\hline 36 & 4 & A & A & $\ldots-\ldots$ & $\mathrm{Z}$ & -..... \\
\hline 38 & A & A & A & $M$ & Z & -..... \\
\hline 41 & A & A & A & M & A & ...... \\
\hline 42 & ..... & 21 & 23 & $\ldots$ & $\mathrm{R}$ & \\
\hline $\begin{array}{l}62 \\
46\end{array}$ & & $\bar{z}$ & $\mathrm{Z}$ & A & $\mathrm{Z}$ & \\
\hline
\end{tabular}

TABLE 5. Condition or maximum penetration of galvanized pipe and 16-gage steel sheet-Continued

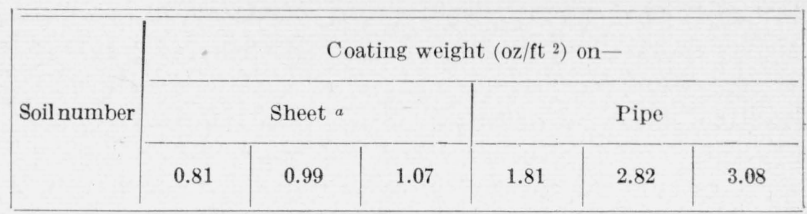

INORGANIC OXIDIZING-ALKALINE SOILS

\begin{tabular}{|c|c|c|c|c|c|c|}
\hline $\begin{array}{l}13 \\
65 \\
66\end{array}$ & $\begin{array}{c}\mathrm{R} \\
\mathrm{B}\end{array}$ & $\begin{array}{c}15 \\
-\cdots\end{array}$ & $\begin{array}{c}8 \\
-\end{array}$ & - & $\begin{array}{c}\mathrm{R} \\
-\end{array}$ & A \\
\hline
\end{tabular}

INORGANIC REDUCING-ACID SOILS

\begin{tabular}{|c|c|c|c|c|c|c|}
\hline $\begin{array}{l}1 \\
2 \\
5 \\
7 \\
9\end{array}$ & $\begin{array}{c}30 \\
\mathrm{R} \\
22 \\
17 \\
19\end{array}$ & $\begin{array}{l}30 \\
\mathrm{~A} \\
12 \\
17 \\
29\end{array}$ & $\begin{array}{r}33 \\
Z \\
12 \\
22 \\
23\end{array}$ & $\begin{array}{l}29 \\
\mathrm{M} \\
\mathrm{R} \\
\mathrm{R}\end{array}$ & $\begin{array}{l}\mathrm{R} \\
\mathrm{Z} \\
\mathrm{R} \\
\mathrm{R} \\
\mathrm{A}\end{array}$ & - \\
\hline $\begin{array}{l}14 \\
17 \\
27 \\
28 \\
30\end{array}$ & $\begin{array}{c}\text { A } \\
27 \\
10 \\
63 \\
13\end{array}$ & $\begin{array}{l}\text { A } \\
22 \\
12 \\
33 \\
20\end{array}$ & $\begin{array}{r}\mathrm{R} \\
19 \\
9 \\
22 \\
11\end{array}$ & $\begin{array}{c}\mathrm{A} \\
\mathrm{R} \\
12\end{array}$ & $\begin{array}{l}\mathrm{Z} \\
\mathrm{R} \\
\mathrm{A} \\
\mathrm{R} \\
\mathrm{A}\end{array}$ & . \\
\hline $\begin{array}{l}37 \\
40 \\
61 \\
44 \\
51\end{array}$ & $\begin{array}{c}17 \\
48 \\
\mathrm{~A}\end{array}$ & $\begin{array}{l}20 \\
47 \\
\mathrm{~A} \\
\end{array}$ & $\begin{array}{c}14 \\
38 \\
\mathrm{~A} \\
\end{array}$ & $\mathrm{R}$ & $\begin{array}{c}\mathrm{R} \\
\mathrm{R}\end{array}$ & $\mathrm{M}^{15}$ \\
\hline
\end{tabular}

INORGANIC REDUCING-ALKALINE SOILS

\begin{tabular}{|c|c|c|c|c|c|c|}
\hline $\begin{array}{r}8 \\
15 \\
20 \\
23 \\
70\end{array}$ & $\begin{array}{c}\mathrm{R} \\
\mathrm{A} \\
21 \\
21\end{array}$ & $\begin{array}{c}\text { A } \\
\text { Z } \\
17 \\
37 \\
\end{array}$ & $\begin{array}{r}\text { A } \\
\text { Z } \\
13 \\
41\end{array}$ & $\begin{array}{c}\mathrm{R} \\
\mathrm{R} \\
\mathrm{R}\end{array}$ & $\begin{array}{c}\mathrm{Z} \\
\mathrm{Z} \\
\mathrm{R} \\
68\end{array}$ & 7 \\
\hline $\begin{array}{l}45 \\
47 \\
56 \\
64\end{array}$ & $\begin{array}{c}5 \\
\mathrm{R}\end{array}$ & $\begin{array}{c}19 \\
\mathrm{R} \\
\end{array}$ & $\begin{array}{c}16 \\
\mathrm{R} \\
\end{array}$ & $\begin{array}{c}38 \\
\mathrm{~A}\end{array}$ & $\begin{array}{c}\mathrm{R} \\
\mathrm{A}\end{array}$ & $\begin{array}{r}17 \\
7\end{array}$ \\
\hline
\end{tabular}

ORGANIC REDUCING-ACID SOILS

\begin{tabular}{|c|c|c|c|c|c|c|}
\hline 29 & 26 & 32 & 28 & 30 & $\mathrm{R}$ & \\
\hline $\begin{array}{l}58 \\
33\end{array}$ & 29 & 17 & 14 & ...... & $\mathrm{R}$ & 65 \\
\hline 43 & $\begin{array}{l}29 \\
63\end{array}$ & $\mathrm{R}$ & $\begin{array}{l}14 \\
\mathrm{R}\end{array}$ & 25 & $\begin{array}{l}\mathrm{R} \\
\mathrm{A}\end{array}$ & ....... \\
\hline 63 & -... & - & -..... & ....... & , & 8 \\
\hline 59 & - & ...... & $\ldots$ & - & $\ldots$ & 8 \\
\hline 60 & ...... & ....... & ...... & - n & - & 75 \\
\hline
\end{tabular}

67

\section{|}

40

a Weights of the coating on one side. This is half the nominal weight of the coating on sheets.

of steel for at least $10 \mathrm{yr}$, assuming reasonably uniform distribution of the coating.

As the pit depth data shown in figure 6 apply to specimens of galvanized steel which were exposed to a variety of soil environments, an optimum weight of coating that might be selected on the basis of these data might be excessive in some specific environment but insufficient in others. In table 5 are shown the depths of the deepest pits on the specimens exposed in the earlier series of tests [1], from which can be determined the minimum weight of coating required to protect steel for $10 \mathrm{yr}$ in specific soil environments. Data for the specimens buried in 1937 are also included in the table. 
It will be observed that in the group of oxidizing, inorganic soils, pitting occurred on the specimens having a weight of coating of $1.07 \mathrm{oz} / \mathrm{ft}^{2}$ or less, but no pits developed on the specimens having a coating of $1.81 \mathrm{oz} / \mathrm{ft}^{2}$. Hence it is reasonable to conclude that a nominal 2-oz coating is probably adequate for oxidizing soils for at least $10 \mathrm{vr}$. A $3-\mathrm{oz}$ coating would provide adequate protection in the group of reducing inorganic soils except for highly reducing soils high in soluble salts, for example, 51 and 56 . These latter soils and the group of reducing organic soils and cinders would require a coating in excess of $3 \mathrm{oz} / \mathrm{ft}^{2}$.

\section{Summary}

This report contains the results of measurements of corrosion made on specimens of galvanized steel, bare steel and zinc exposed to different soil conditions for periods up to $13 \mathrm{yr}$. The nominal weight of the zinc coating was $3 \mathrm{oz} / \mathrm{ft}^{2}$, but the actual thickness varied over a wide range. In approximately one-half of the 15 soils to which the specimens were exposed, the coating on the galvanized specimens remained virtually intact throughout the entire duration of the field test. The galvanized specimens were especially resistant to corrosion in alkaline soils that were highly corrosive to bare steel. In only two soils, both organic, failure of the zinc coating after relatively short exposures was accompanied by marked corrosion of the steel. The high corrosion resistance shown by most of the galvanized specimens after the outer zinc coating had been virtually removed by corrosion is tentatively attributed to a film or coating, probably silicious in nature, that was deposited cathodically by galvanic action between the outer zine coating and the alloy layer or the underlying steel.

The results of these tests show that the minimum weight of zinc coating required to protect steel from corrosion for a minimum of $10 \mathrm{yr}$ depends on the nature of the soil environment. In these exposure tests, a 2-oz coating was sufficient to protect steel in inorganic oxidizing soils, but for inorganic moderately reducing soils a 3-oz coating was required. Highly reducing, inorganic and organic soils require coatings in excess of $3 \mathrm{oz} / \mathrm{ft}^{2}$.

The field tests described were initiated and installed, and until 1946 were conducted under the supervision of K. H. Logan.

\section{References}

[1] Kirk H. Logan and Scott P. Ewing, J. Research NBS 18, 361 (1937) RP 982.

[2] Kirk H. Logan, NBS Circular C450 (1945).

[3] A. Brenner, J. Research NBS 20, 357 (1938) RP1081.

[4] S. C. Britton, J. Inst. Metals 58, 211 (1936).

[5] Stanley Anderson and R. W. Manuel, Trans. Electrochem. Soc. 78, 373 (1940).

[6] William Blum and Abner Brenner, Corrosion Handbook, p. 814. John Wiley \& Sons, Inc., New York 1, N. Y. (1948). 

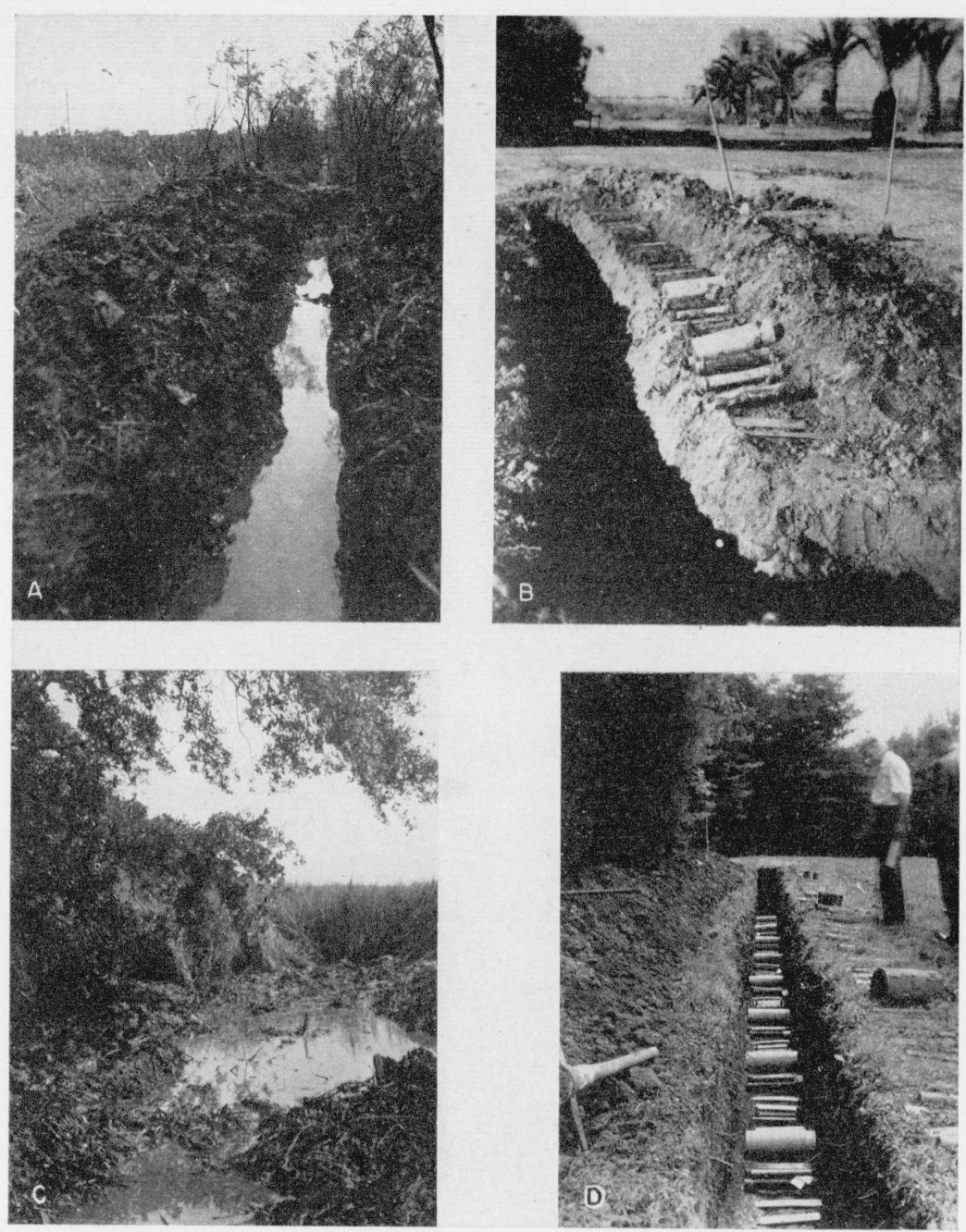

Figure 1. Environmental conditions at typical test sites. A, site 56, Lake Charles clay at El Vista, Texas; B, site 70, Merced silt loam at Buttonwillow,
Calif.; C, site 63, tidal marsh at Charleston, S. C.; D, site 55, Hagerstown loam at Loch Raven, Md.

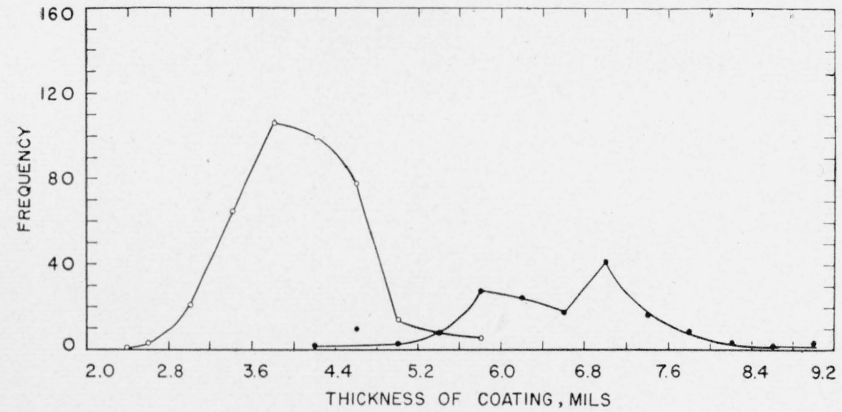

Figure 2. Distribution of coating on test specimens.

Specimen A; length, 14 in.; number of observations, 389. - Specimen B;

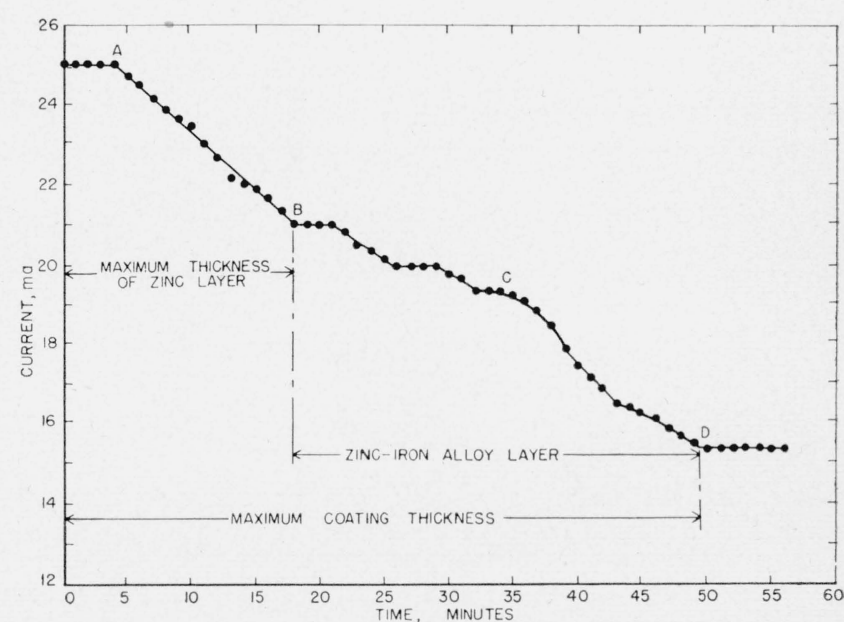

FIGURE 3. Thickness of the outer zinc coating and of the alloy layer. 


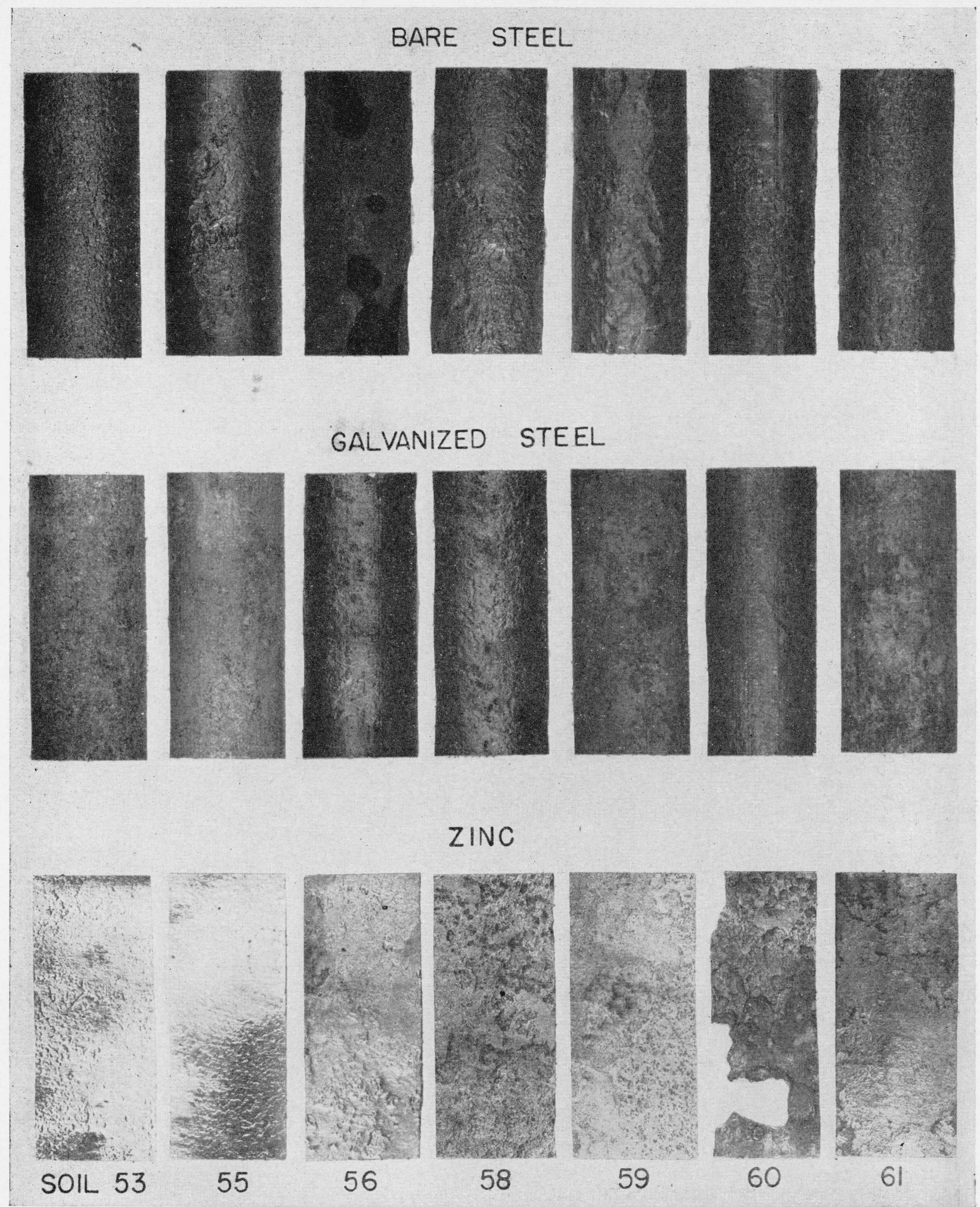

FiguRE 4. Condition of specimens of bare steel, galvanized steel, and zinc after exposure for 13 yr to 14 soils. 


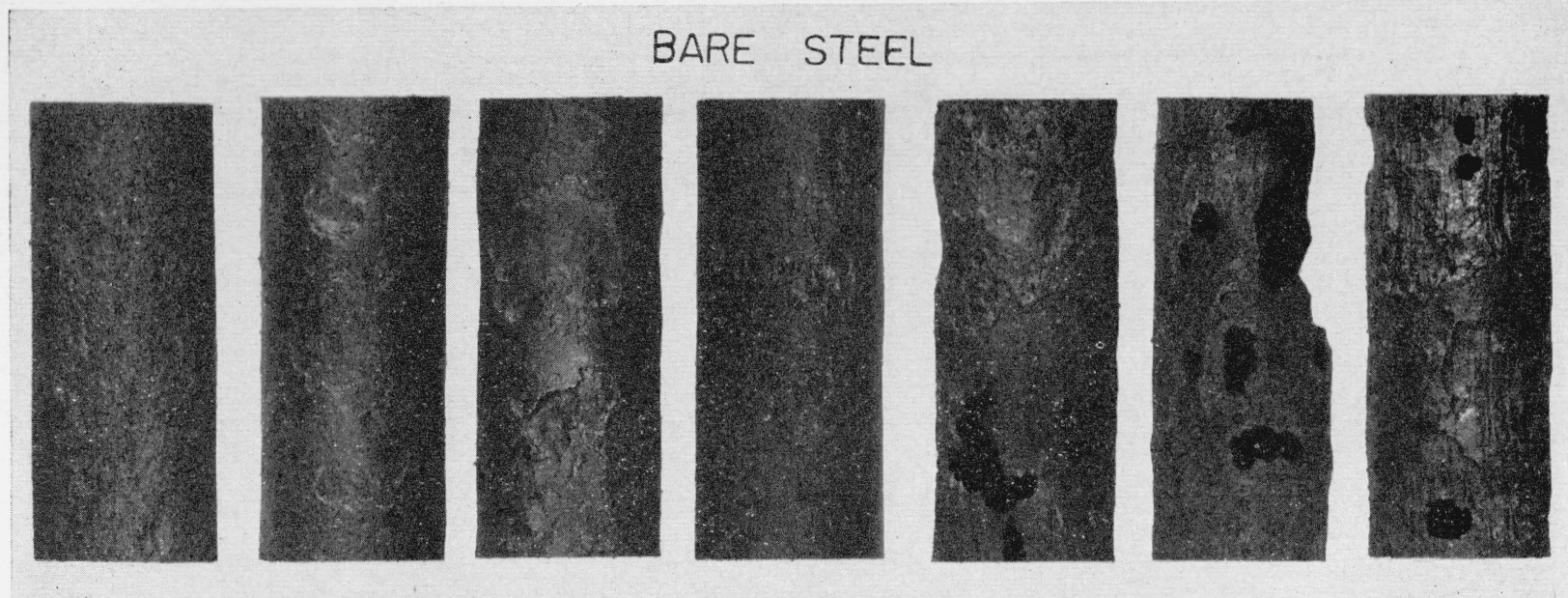

\section{GALVANIZED STEEL}
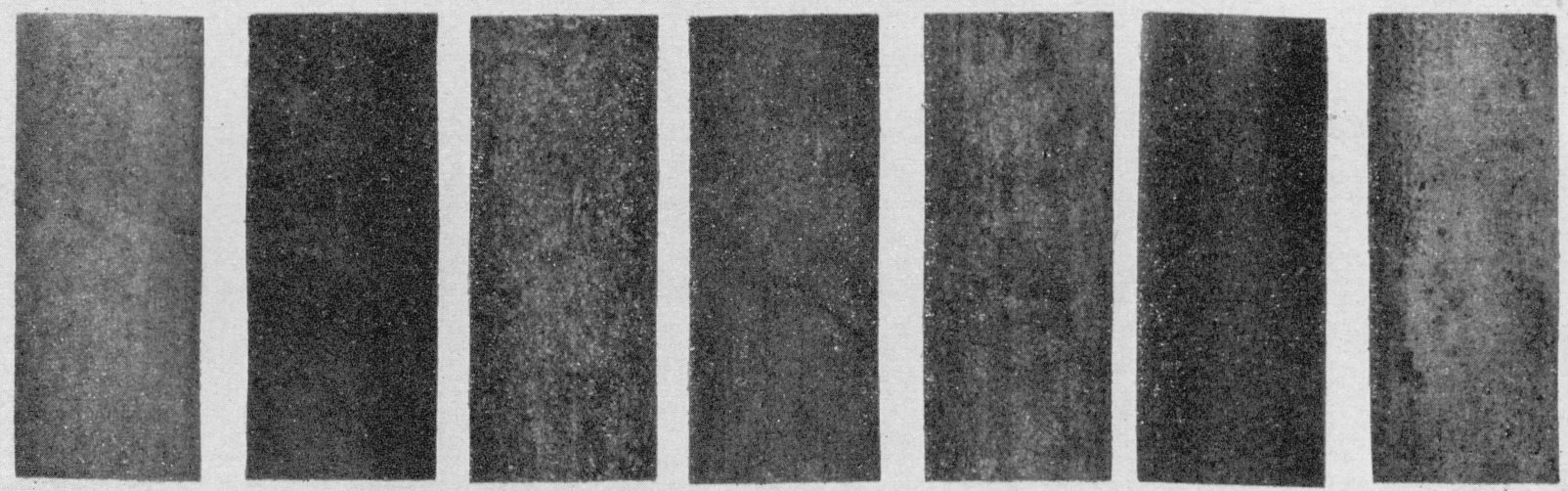

\section{ZINC}

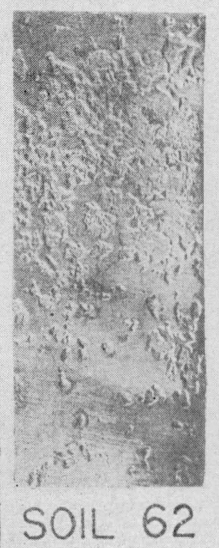

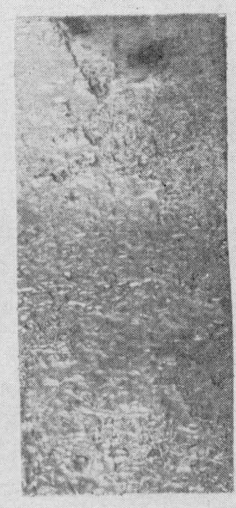

63

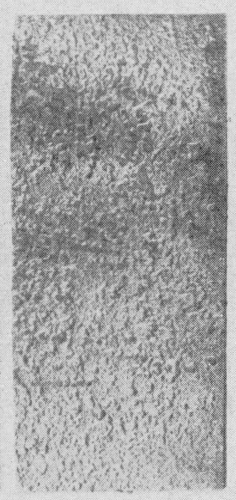

64

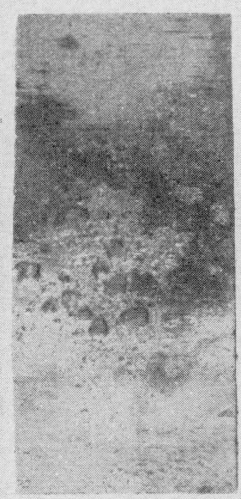

65

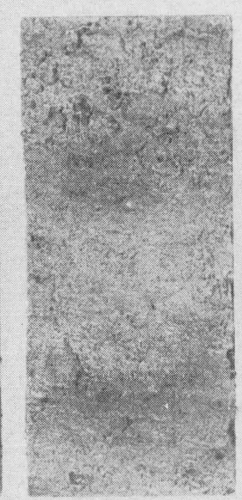

66

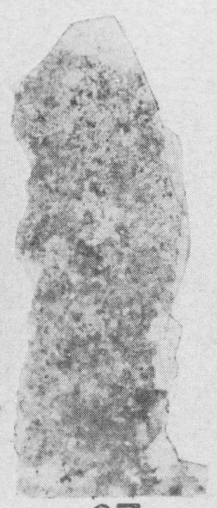

67

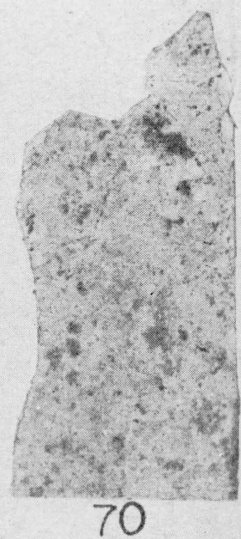

Figure 4. Condition of specimens of bare steel, galvanized steel, and zinc after exposure for 13 yr to 14 soils.-Continued 
INORGANIC OXIDIZING SOILS
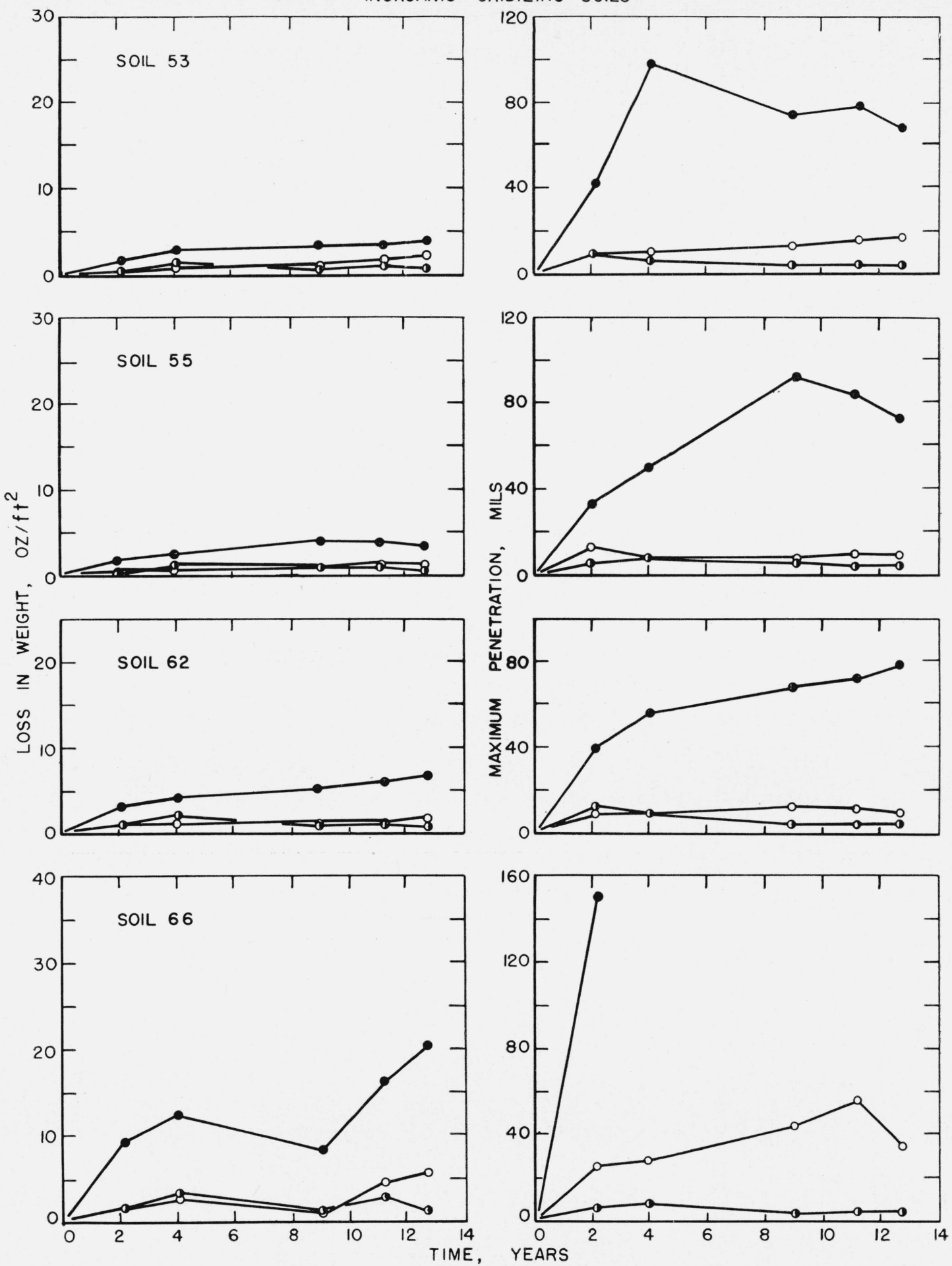

FIGURE 5. Weight-loss and maximum-penetration-time curves of galvanized steel, bare steel, and zinc.

- Bare steel, $\bigcirc$ zinc, Galvanized steel. 
INORGANIC OXIDIZING SOILS
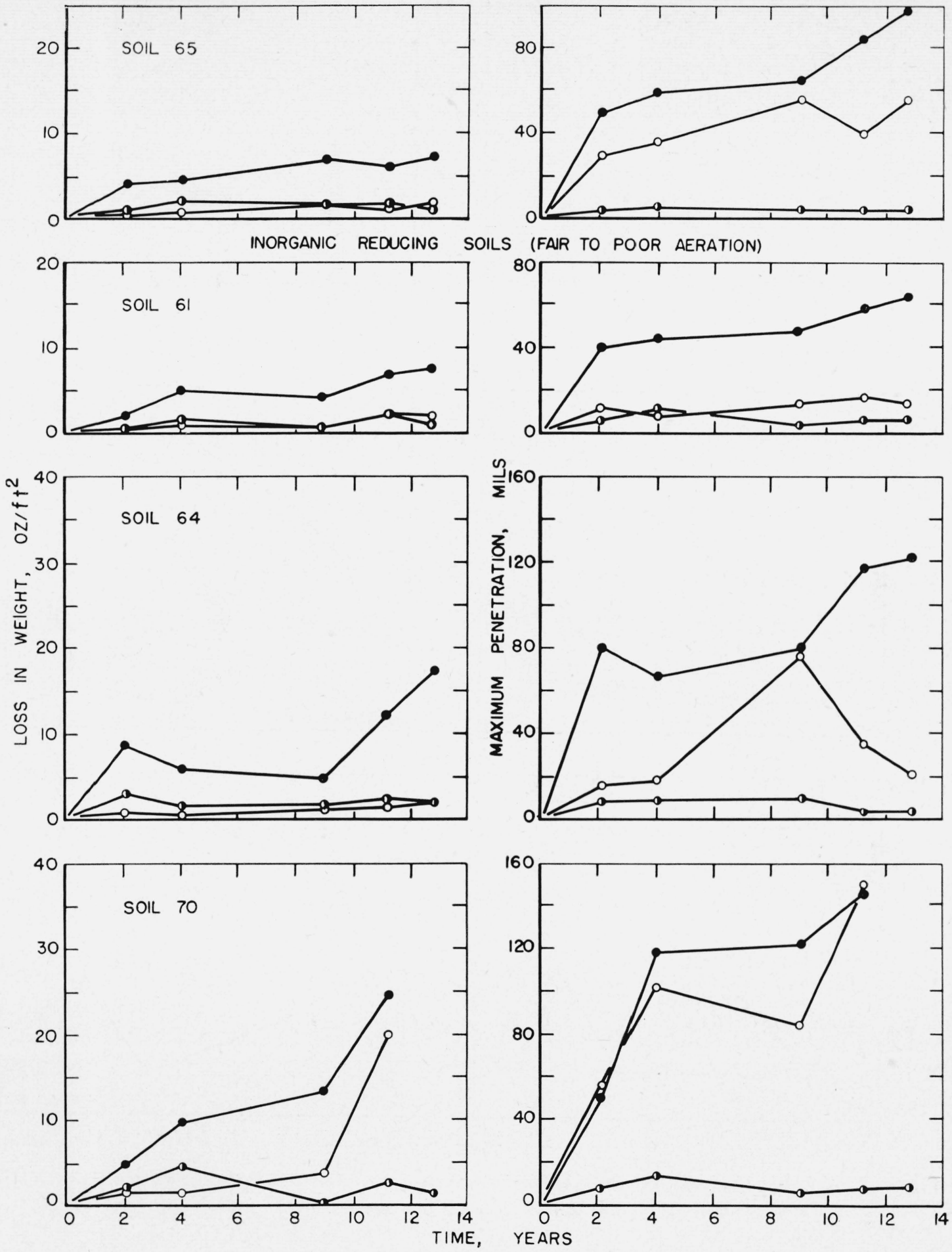

FIGURE 5. Weight-loss and maximum-penetration-time curves of galvanized steel, bare steel, and zinc-Continued - Bare steel, $\bigcirc$ zinc, Galvanized steel. 
INORGANIC REDUCING

SOILS (VERY POOR AERATION)
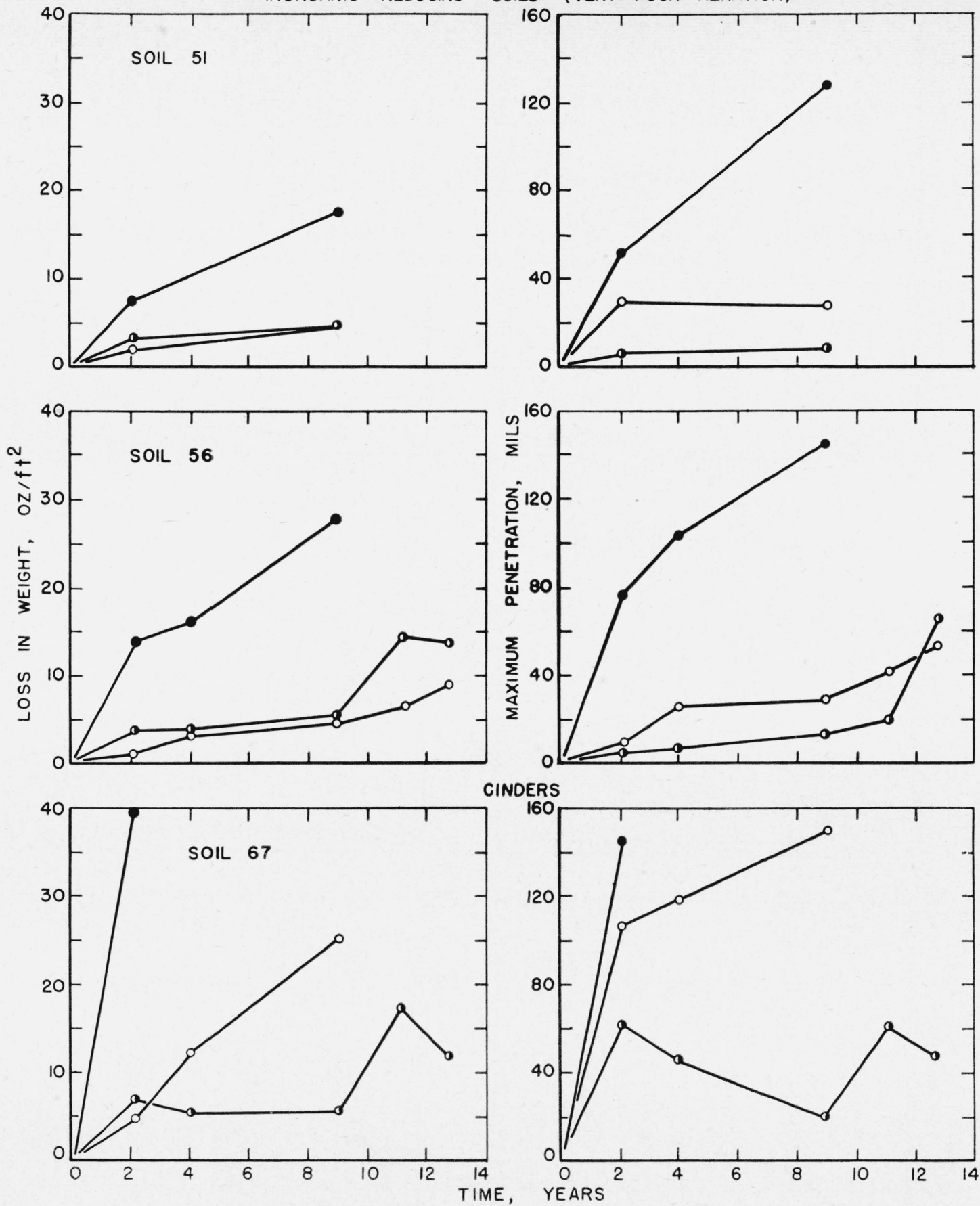

CINDERS

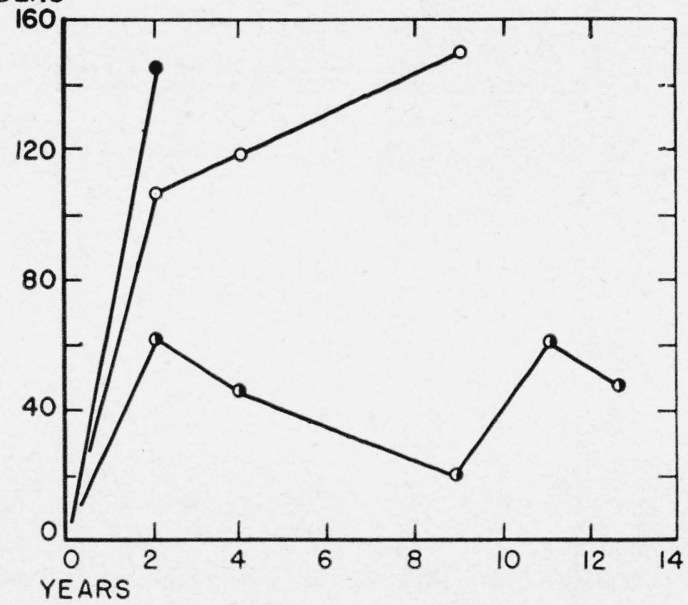

FIGURE 5. Weight-loss and maximum-penetration-time curves of galvanized steel, bare steel, and zinc-Continued - Bare steel, $\bigcirc$ zinc, galvanized steel. 
ORGANIC REDUCING SOILS
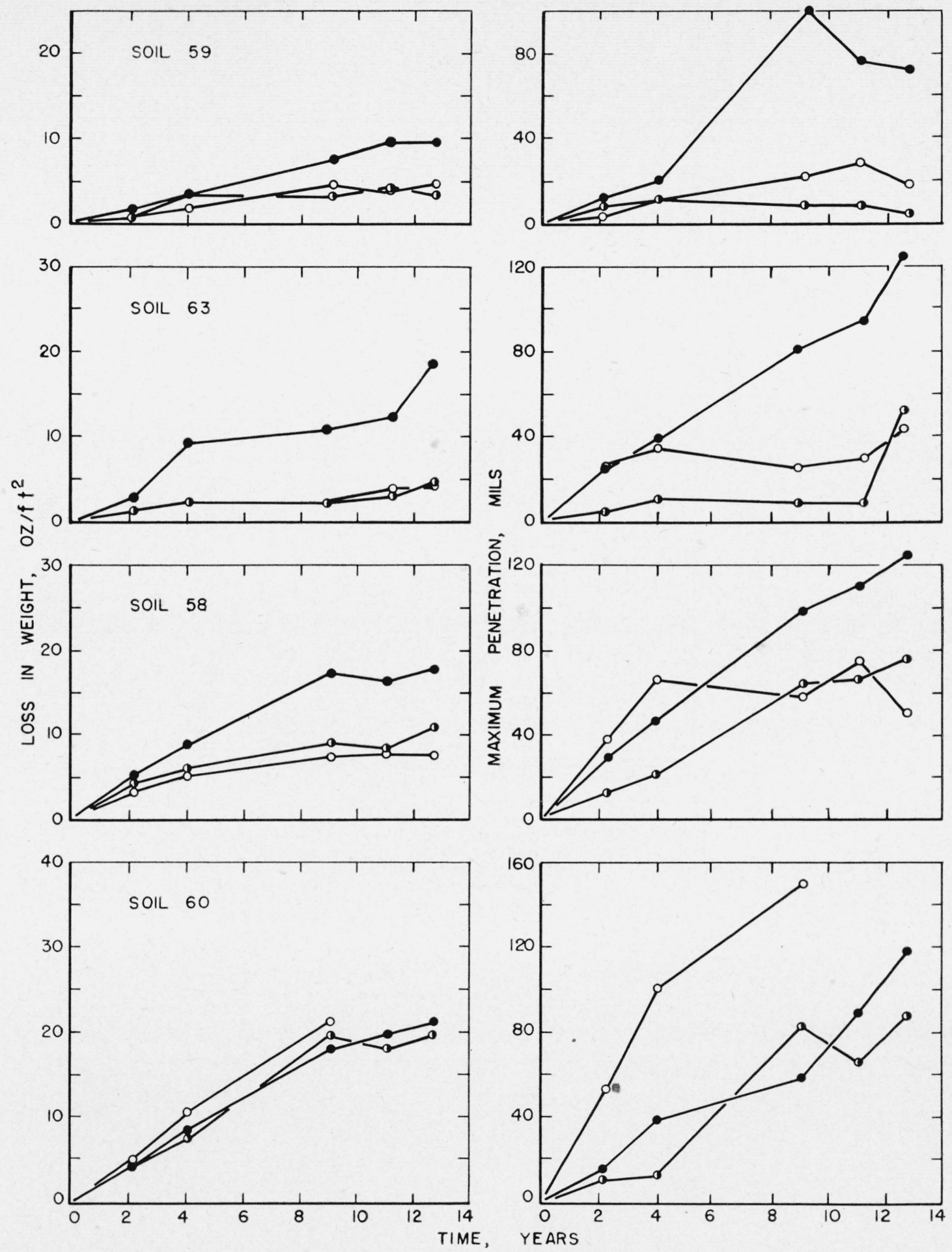

FIGURE 5. Weight-loss and maximum-penetration-time curves of galvanized steel, bare steel, and zinc-Continued - Bare steel, $\bigcirc$ zine, galvanized steel. 


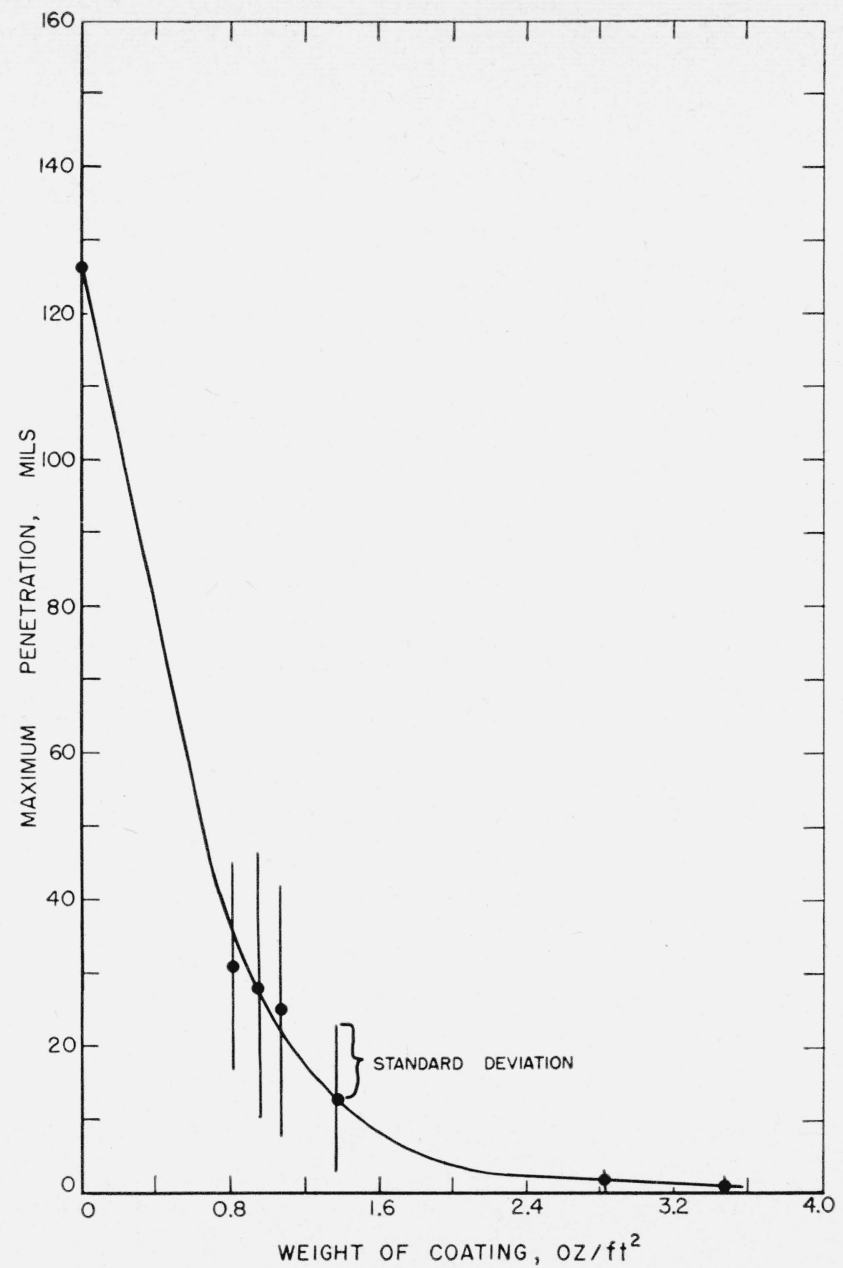

FIGURE 6. Correlation between maximum penetration and weight of coating on galvanized pipe and sheet exposed $10 \mathrm{yr}$ in 6 soils.

(Data of Logan and Ewing.)

Washington, August 18, 1952. 